\title{
MICROBIAL ALTERATIONS OF THE SOIL INFLUENCED BY INDUCED COMPACTION ${ }^{(1)}$
}

\author{
Breno Pupin ${ }^{(2)}$, Onã da Silva Freddi ${ }^{(3)} \&$ Ely Nahas ${ }^{(4)}$
}

\begin{abstract}
SUMMARY
Compaction is one of the most destructive factors of soil quality, however the effects on the microbial community and enzyme activity have not been investigated in detail so far. The objective of this study was to evaluate the effects of soil compaction caused by the traffic of agricultural machines on the soil microbial community and its enzyme activity. Six compaction levels were induced by tractors with different weights driving over a Eutrustox soil and the final density was measured. Soil samples were collected after corn from the layers $0-0.10$ and 0.10 $0.20 \mathrm{~m}$. The compaction effect on all studied properties was evident. Total bacteria counts were reduced significantly (by 22-30 \%) and by 38-41 \% of nitrifying bacteria in the soil with highest bulk density compared to the control. On the other hand, fungi populations increased 55-86\% and denitrifying bacteria $49-53 \%$. Dehydrogenase activity decreased 20-34 \%, urease 44-46 \% and phosphatase 26$28 \%$. The organic matter content and soil $\mathrm{pH}$ decreased more in the $0-0.10$ than in the $0.10-0.20 \mathrm{~m}$ layer and possibly influenced the reduction of the microbial counts, except denitrifying bacteria, and all enzyme activities, except urease. Results indicated that soil compaction influences the community of aerobic microorganisms and their activity. This effect can alter nutrient cycling and reduce crop yields.
\end{abstract}

Index terms: microorganisms, enzymes, corn.

\footnotetext{
(1) Recebido para publicação em agosto de 2008 e aprovado em julho de 2009.

(2) Doutorando do Programa de Pós-Graduação em Microbiologia. Faculdade de Ciências Agrárias e Veterinárias - UNESP. Via de Acesso Prof. Paulo Donato Castellane s/n, CEP 14884-900 Jaboticabal (SP). E-mail: breno@posgrad.fcav.unesp.br

${ }^{(3)}$ Pós-Doutorando do Departamento de Solos e Adubos. Faculdade de Ciências Agrárias e Veterinárias, UNESP. Bolsista da FAPESP. E-mail: onafreddi@fcav.unesp.br

(4) Professor Titular do Departamento de Produção Vegetal, Faculdade de Ciências Agrárias e Veterinárias, UNESP/Jaboticabal. Bolsista do CNPq. E-mail: enahas@fcav.unesp.br
} 


\title{
RESUMO: ALTERAÇÕES MICROBIANAS DO SOLO INFLUENCIADAS POR COMPACTAÇÃO INDUZIDA
}

\begin{abstract}
A compactação é um dos fatores mais agravantes para a qualidade do solo, porém o seu efeito na comunidade e atividade enzimática microbiana não tem sido suficientemente estudado. Seis niveis de compactação foram obtidos pela passagem de tratores com diferentes pesos em um Latossolo Vermelho, e a densidade final foi medida. Amostras de solo foram coletadas nas profundidades de 0-10 e 10-20 cm, após a colheita do milho. O efeito da compactação foi evidente em todos os parâmetros estudados, mas nem sempre foi significativo. A contagem das bactérias totais reduziu significativamente em $22-30 \%$, e a das nitrificantes, em 38-41\%, no solo com maior densidade em relação ao controle. Contudo, a população de fungos aumentou de 55 a $86 \%$, e a das bactérias desnitrificantes, de 49 a $53 \%$. A atividade da desidrogenase diminuiu de 20 a $34 \%$; a da urease, de 44 a $46 \%$; e a da fosfatase, de 26 a $28 \%$. $O$ conteúdo de matéria orgânica e o $\mathrm{pH}$ do solo diminuíram na camada 0-0,10 em relação à de 0,10-0,20 m e influíram possivelmente na redução das contagens microbianas exceto das bactérias desnitrificantes, e na atividade das enzimas, menos a da urease. Esses resultados indicam que a compactação do solo teve influência na comunidade de microrganismos aeróbios e na sua atividade. Esse efeito pode alterar a ciclagem de nutrientes e diminuir a produção da planta.
\end{abstract}

Termos de indexação: microrganismos, enzimas, milho, compactação.

\section{INTRODUCTION}

Modern agriculture is based on an intensive use of agricultural equipment for soil handling and fertilizer and pesticide application. Intense traffic by agricultural machinery causes compaction and, as a consequence, changes the soil physically and reduces plant productivity (Lanzanova et al., 2007). The combination of these factors can diminish crop yields compared to uncompacted areas. In addition, macroporosity and total porosity are reduced, increasing soil density and making root penetration more difficult (Giarola et al., 2007). A study with corn seedlings showed that an increased global soil density resulted in reduced length and number of seminal adventitious roots (Rosolem et al., 1999). Although innumerable studies have studied the effect of compaction on soil physical properties and plant development, few studies have focused on the dynamics of microorganism populations and enzymes involved in the soil metabolic processes.

Soil enzymes and microbial activities are sensitive to abrupt environmental changes. Compaction can influence the plant-available nutrients because the number and activity of microorganisms may be diminished. (Lee et al., 1996). Li et al. (2003), for example, showed a reduction in biomass and microbial activity. Populations of bacteria, total fungi, nematodes, and arthropods were significantly larger in control than in compacted soil (Smeltzer et al., 1986). Breland \& Hansen (1995) reported an $18 \%$ reduction in the mineralization of organic ${ }^{15} \mathrm{~N}$ from clover in compacted soil compared to the control.

The main effect of compaction consists in altering the availability of soil aeration due to the loss of biopores and other macropores (Whalley et al., 1995, Lima et al., 2005). Anaerobiosis conditions tend to modify the predominant microbial populations which transform nutrients in the soil. Under controlled conditions, the higher $\mathrm{N}$ loss was related to the increase in soil density and saturation as a consequence of denitrification (Torbert \& Wood, 1992; Jordan et al., 2003). Soil nitrification is generally catalyzed by aerobic bacteria, whereas denitrification is favored by anaerobic conditions. The increase of anaerobiosis due to excess rainfall and pore saturation resulted in significant $\mathrm{N}_{2} \mathrm{O}$ loss from the $\mathrm{N}$ fertilizers (Clayton et al., 1997). Denitrifying bacteria were predominant in compacted soil, which increased $\mathrm{N}_{2} \mathrm{O}$ emission in potato (Ruser et al., 2006).

Microbial enzymes have essential functions in the soil and have been used to measure the influence of soil management and quality (Bergstrom et al., 1998). Enzyme activity may hinder or foster nutrient cycling and crop yields, apart from causing soil physical and chemical alterations (Martens et al., 1992; Dick et al., 1997). Organic matter is usually seen as an indicator of soil quality and biological transformations, and is a source of information regarding soil management (Riffaldi et al., 2003; Garcia \& Nahas., 2007; Araújo \& Monteiro, 2007). The objective of this study was to evaluate the effect of compaction caused by agricultural machinery on the soil microbial community and enzyme activity.

\section{MATERIALS AND METHODS}

This study was conducted at the Faculdade de Ciências Agrárias e Veterinárias, (FCAV/UNESP) in 
Jaboticabal, state of São Paulo (lat. $21^{\circ} 15^{\prime} 29$ ” S, long. $48^{\circ} 16^{\prime} 47 ” \mathrm{~W}, 614 \mathrm{~m}$ asl). The climate, according to Köppen, was classified as Cwa, with hot summers and dry winters. The mean annual medium is $21^{\circ} \mathrm{C}$ and rainfall $1,428 \mathrm{~mm}$.

To simulate different compaction levels, tractors weighing $4 \mathrm{t}$ (treatment $\mathrm{b}$ ) and $11 \mathrm{t}$ (other treatments) were driven across the fields and the resulting soil density (D) was measured. The treatments were: (a) area free of agricultural traffic $(\mathrm{D}=1.35)$; (b) one pass of the tractor $(\mathrm{D}=1.62)$; (c) one pass $(\mathrm{D}=1.66)$; $(\mathrm{d})$ two passes $(\mathrm{D}=1.70)$; (e) four passes $(\mathrm{D}=1.73)$; and (f) six passes $(\mathrm{D}=1.74)$. The triple Master hybrid corn was cultivated in October, 2004, at a spacing of $90 \mathrm{~cm}$ between rows, in medium typical dystrophic texture Red Latosol soil with moderate hypoferric kaolinitic (LVd). The crop was fertilized at the beginning with $0.3 \mathrm{Mg} \mathrm{ha}^{-1}$ of the compound fertilizer 10-20-20 after plant emergence and later with $0.3 \mathrm{Mg} \mathrm{ha}^{-1}$ of ammonium sulfate by covering 28 days after plant emergence. The specific soil characteristics and form of cultivation were reported by Freddi et al. (2007).

Soil samples were collected after the corn harvest at depths of $0-10$ and $10-20 \mathrm{~cm}$ by a screw auger. Five simple samples were taken from each plot, which were combined in a composite sample, for a total of eight treatment samples: four each from the $0-10 \mathrm{~cm}$ and $10-20 \mathrm{~cm}$ layer. The samples were sifted through a $2 \mathrm{~mm}$ mesh sieve and divided into two fractions: one part was kept in a refrigerator until the microbiological analysis and the other part was airdried and conserved at room temperature for chemical analysis.

The culture media of Bunt \& Rovira (1955) and of Martin (1950) were used to quantify the number of colony-forming units (CFU) of bacteria and total fungi, respectively. The most probable number (MPN) of denitrifying and nitrifying bacteria was determined according to Alexander (1982), using the culture media proposed by Alexander (1965) and Schmidt \& Belser (1982), respectively. The incubation time at $30^{\circ} \mathrm{C}$ was $24 \mathrm{~h}$ for total bacteria, $48 \mathrm{~h}$ for total fungi, 4 days for nitrifying bacteria, and 7 days for denitrifying bacteria.

The activity of urease, acid phosphatase, and dehydrogenase enzymes was determined according to McGarity \& Myers (1967), Tabatabai \& Bremner (1969), and Casida Jr. et al. (1964), respectively. Urease activity was expressed as $\mu \mathrm{g} \mathrm{NH}_{4}-\mathrm{N} \mathrm{g}^{-1}$ dry soil $3 \mathrm{~h}^{-1}$, acid phosphatase as $\mu \mathrm{g}$ p-nitrofenol $\mathrm{g}^{-1}$ dry soil $\mathrm{h}^{-1}$, and dehydrogenase as $\mu \mathrm{g}$ triphenylformazan $\mathrm{g}^{-1}$ dry soil $24 \mathrm{~h}^{-1}$.

Soil moisture was determined after drying soil samples at $105^{\circ} \mathrm{C}$ to constant weight and organic matter by oven incineration at $550{ }^{\circ} \mathrm{C}$ for $24 \mathrm{~h}$. The soil $\mathrm{pH}$ was measured in a mixture containing $10 \mathrm{~cm}^{3}$ soil and $25 \mathrm{~mL} 0.01 \mathrm{~mol} \mathrm{~L}^{-1} \mathrm{CaCl}_{2} .2 \mathrm{H}_{2} \mathrm{O}$.
The experiment was arranged in a split-plot design with four replications. Each experimental plot consisted of five 3-m-long corn rows, where only three rows were evaluated. The different compaction levels were considered in the plots, and the sampling soil depths in the subplots. Results were submitted to variance analysis using software SAS (1990) and means were compared by the Tukey test $(p<0.05)$.

\section{RESULTS}

The number of bacteria decreased progressively and significantly (Tukey, $\mathrm{p}<0.05$ ), up to $30 \%$ at $0-$ $10 \mathrm{~cm}$ and $22 \%$ at $10-20 \mathrm{~cm}$ depth, when $\mathrm{D}_{1.74}$ was compared with the control soil $\left(\mathrm{D}_{1.35}\right)$ (Figure 1a). Fungi counts $(p<0.05)$ were largest in the highest density soils $\left(\mathrm{D}_{1.73}\right.$ and $\left.\mathrm{D}_{1.74}\right)$ and decreased in the lower density soils (Figure 1b). The MPN of nitrifying bacteria increased in the $\mathrm{D}_{1.62}(0-10 \mathrm{~cm})$ and $\mathrm{D}_{1.66}$ $(10-20 \mathrm{~cm})$ soils, but decreased as soil density increased (Figure $2 a)$. The decrease $(p<0.05)$ in MPN of nitrifying bacteria in $\mathrm{D}_{1.74}$ soil varied $38-41 \%$
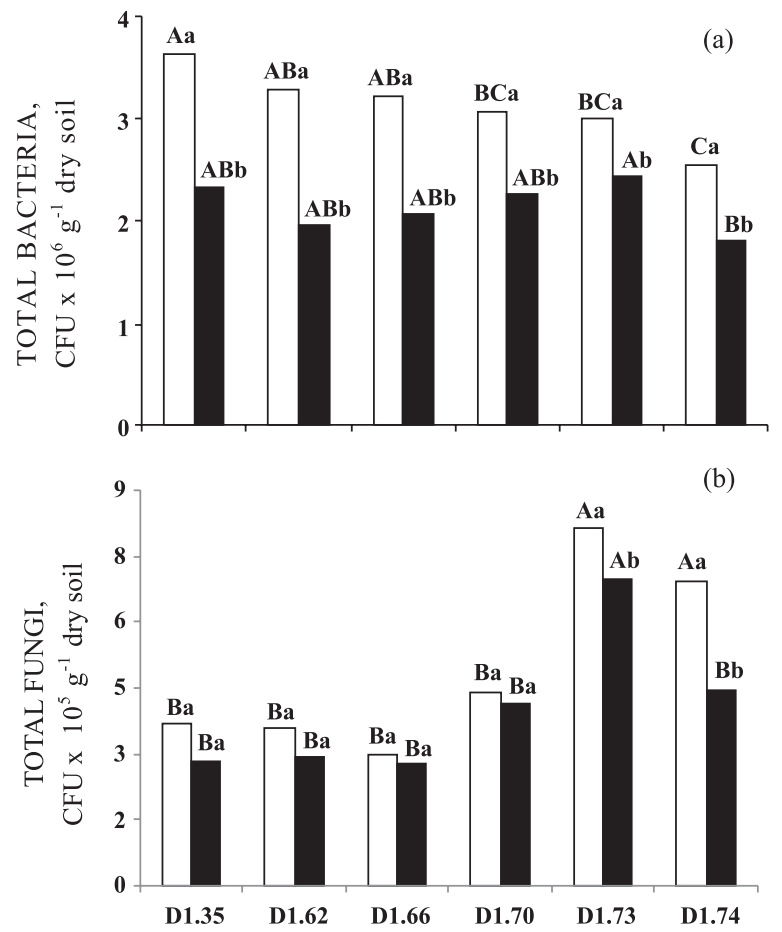

Figure 1. Bacteria (a) and fungi (b) populations observed in the layers 0-10 (口) and 10-20 cm (D) of the soil. Bars with the same letter (capital letter: density, and lower-case letter: soil depth) are not significant $(p<0.05)$ different. CFU, colony forming units; Bacteria: $F$ test: density (D) $=5.51^{* *}$; depth $(\mathrm{P})=158.39^{* * * * ;}$ DxP $=2.66^{*}$. Fungi: $F$ test: $D=53.51^{* * * ;} ; \mathrm{P}=12.82^{* * *}$; $\mathrm{DxP}$ $=1.82$ NS. $* p<0.05 ; * * p<0.01 ; * * * p<0.001$; NS, not significant. 


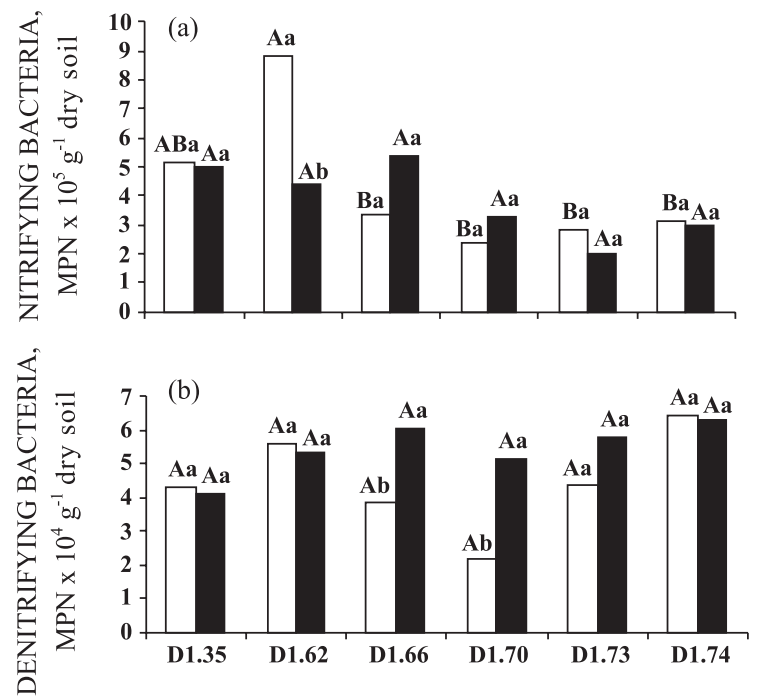

Figure 2. Nitrifying (a) and denitrifying (b) populations found in the layers 0-10 ( $\square$ ) and $10-20 \mathrm{~cm}(\square)$ of the soil. Bars with the same letter (capital letter: density, and lower-case letter: soil depth) are not significant $(p<0.05)$ different. NMP, most probable number; Nitrifying: F test: density $(D)=5.00 *$; depth $(P)=$ 0.47NS; DxP = 0.93NS. Denitrifying: F test: $(D)=$ 1.14NS; $(\mathrm{P})=7.09 * ; \mathrm{DxP}=1.68 \mathrm{NS}$. * $\mathrm{p}<0.05$; NS, not significant.

compared to the control. The MPN of denitrifying bacteria in the $0-10 \mathrm{~cm}$ layer rose initially with the increasing soil density; however, decreased in the $\mathrm{D}_{1.66}$ and $\mathrm{D}_{1.70}$ soils, but later increased (Figure $2 \mathrm{~b}$ ). The MPN growth of denitrifying bacteria in the $D_{1.74}$ soil was $49-53 \%$ in relation to the control, which was the highest $(\mathrm{p}<0.05)$ of both soil depths.

When comparing the $0-10 \mathrm{~cm}$ layer to the 10 $20 \mathrm{~cm}$ layer, the mean bacteria and total fungi counts decreased but the denitrifying bacteria increased significantly. The MPN of nitrifying bacteria decreased only $9 \%$.

Increased soil compaction affected the activity of dehydrogenase, urease, and acid phosphatase enzymes (Figures 3 and 4). Dehydrogenase activity decreased with increased soil density; a significant decrease of $20 \%$ was found in the $0-10 \mathrm{~cm}$ and $34 \%$ in the 10 $20 \mathrm{~cm}$ layer, when the activity in the $\mathrm{D}_{1.74}$ soil was compared with the control (Figure 3). Similar results were found with urease activity, which decreased by 46 and $44 \%$, respectively (Figure 4a). Phosphatase activity decreased significantly with increasing soil density compared to the control; the decrease was greatest in the $D_{1.74}$ soil, $28 \%$ in the $0-10 \mathrm{~cm}$ and $26 \%$ in the 10-20 cm layer, compared to the control (Figure 4b).

The means of the soil layers $0-10$ and $10-20 \mathrm{~cm}$ showed that only dehydrogenase and phosphatase activities decreased significantly (43 and $7 \%$, respectively).

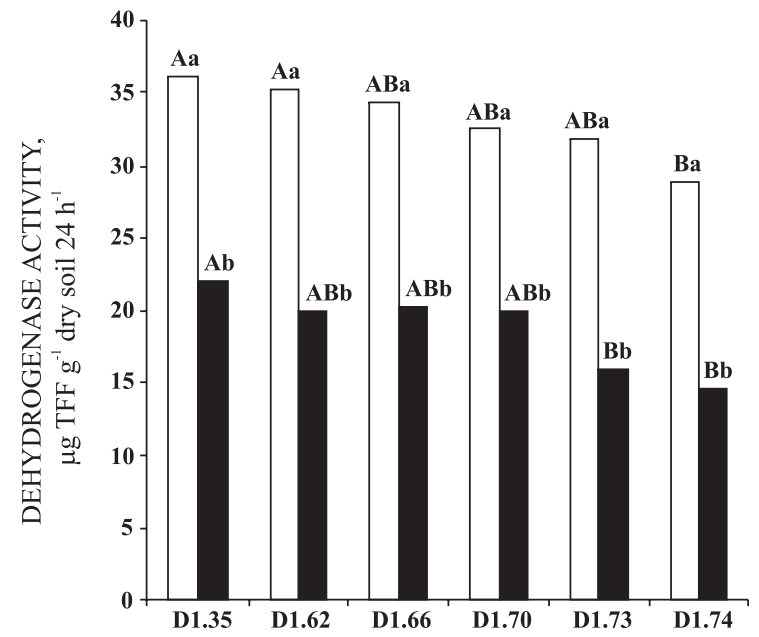

Figure 3. Dehydrogenase activity observed in the

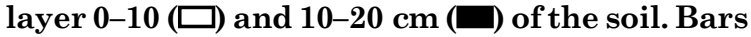
with the same letter (capital letter: density, and lower-case letter: soil depth) are not significant $(p<0.05)$ different. $F$ test: density $(D)=9.79 * *$; depth $(\mathrm{P})=269.95^{* * * ;} ; \mathrm{DxP}=0.28 \mathrm{NS}$. ** $\mathrm{p}<0,01$; **** $\mathrm{p}<0.001$; NS, not significant. TFF, triphenylformazan.
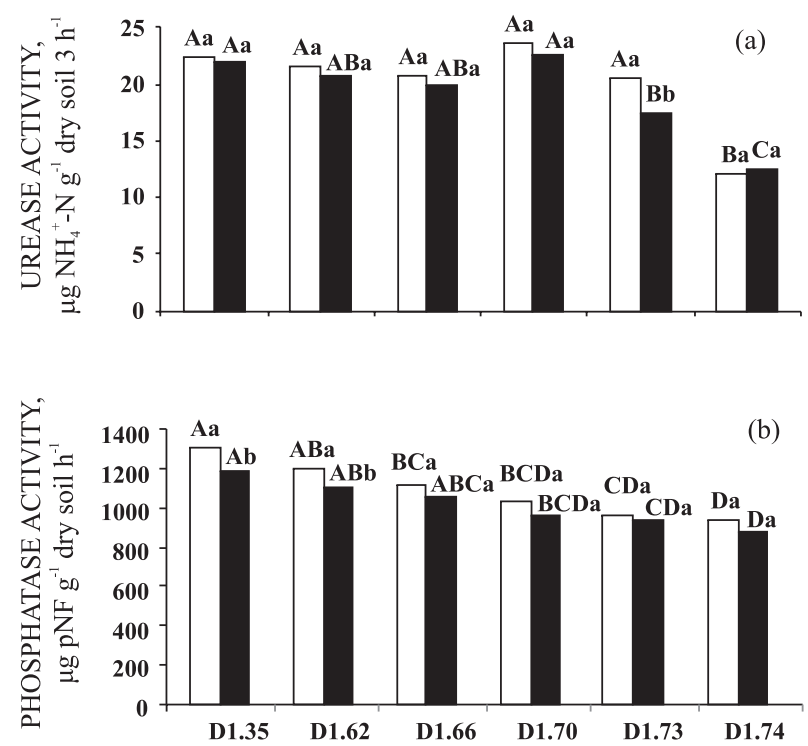

Figure 4. Urease (a) and acid phosphatase (b) activities found in the layers 0-10 ( $\square$ ) and 10$20 \mathrm{~cm}(\square)$ of the soil. Bars with the same letter (capital letter: density, and lower-case letter: soil depth) are not significant $(p<0.05)$ different. Urease: $F$ test: $\operatorname{density}(D)=75.00 * * * ; \operatorname{depth}(P)=$ 2.84NS; DxP $=0.79 \mathrm{NS}$. Acid phosphatase: $\mathrm{F}$ test: (D) $=15.51^{* * * ;} ;(\mathrm{P})=16.76^{* * *} ; \mathrm{DxP}=0.46 \mathrm{NS}$. *** p < 0.001; NS, not significant. pNF, p-nitrofenol.

Figure 5 illustrates that compaction influenced moisture significantly, but not organic matter or soil $\mathrm{pH}$. The moisture content slightly increased with compaction, $6 \%$ in the $\mathrm{D}_{1.74}$ soil in relation to the 
control $(\mathrm{p}<0.05)$ (Figure 5a). While the mean moisture content (Figure 5a) increased $13 \%$ with soil depth, organic matter (Figure 5b) and soil $\mathrm{pH}$ (Figure 5c) decreased 3 and $5 \%$, respectively.
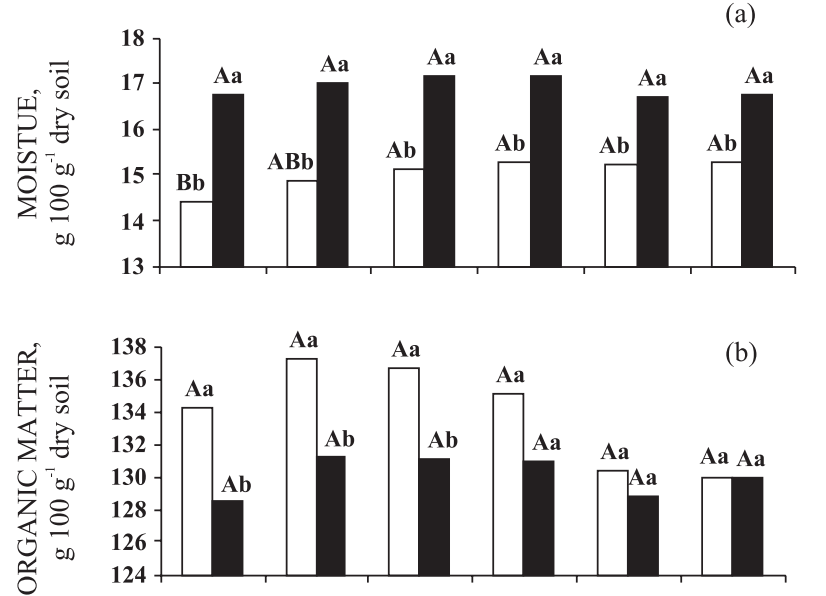

(c)

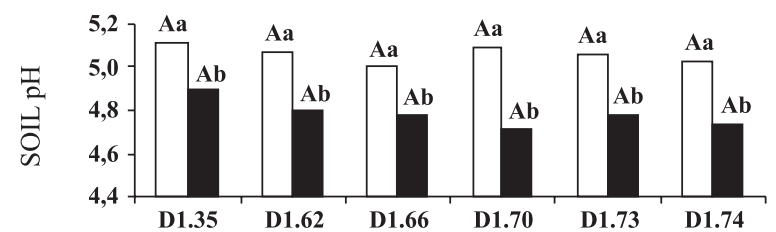

Figure 5. Moisture (a) and organic matter (b) contents and pH (c) found in the layers 0-10 ( $\square)$ and $10-20 \mathrm{~cm}(\square)$ of the soil. Bars with the same letter (capital letter: density, and lower-case letter: soil depth) are not significant $(p<0.05)$ different. Moisture: F test: density $(D)=3.79 \%$; depth $(P)=473.04 * * ; \quad D x P=2.79 *$. Organic matter: $F$ test: $(D)=2.58 \mathrm{NS} ;(\mathrm{P})=10.41 * * ; \mathrm{DxP}=$ 0.69NS. pH: F test: $(D)=2.42 \mathrm{NS} ;(\mathrm{P})=114.73 * * *$; DxP $=0.85$ NS. * $p<0.05 ; * * p<0.01 ; * * * p<0.001$; NS, not significant.

\section{DISCUSSION}

The community of total and nitrifying bacteria was sensitive to the increase in soil density; however, the fungi and denitrifying bacteria benefited. The effect of compaction in reducing bacteria and fungi populations had been observed by Smeltzer et al. (1986). Therefore, increased soil compaction may have restricted the growth of total and nitrifying bacteria but favored denitrifying bacteria. Some factors may explain the results of this study. As density increased, soil macroporosity (Freddi et al., 2007) and $\mathrm{O}_{2}$ availability decreased (Pengthamkeerati et al., 2006; Miransari et al., 2007). Limited soil aeration might therefore inhibit the growth of aerobic microorganisms.

Compaction caused by machinery traffic for corn cultivation under conventional tillage in the $0-12 \mathrm{~cm}$ layer increased bulk density and penetration resistance, reducing root abundance (Taboada et al., 2008). However, despite the physical consequences of soil compaction, root growth increased in the $0-10 \mathrm{~m}$ layer, although corn yields decreased (Freddi et al., 2007). The decreased corn productivity may have been a consequence of the decreased amount of roots and exudation. Since the restriction of the bacterial community depends on the exudates for growth, the transformations of soil nutrients required by the crops would also be limited (Lee et al., 1996). The increase of the denitrifying bacteria community in high-density soils can result in $\mathrm{N}$ loss due to the dessimilatory nitrate reduction and decrease $\mathrm{N}$ availability for corn. In fact, the higher $\mathrm{N}_{2} \mathrm{O}$ emission, observed in compacted forest soil, confirms the stimulation of denitrifying bacteria activity (Teepe et al., 2004). According to Smeltzer et al. (1986), fungi are important agents in soil and the number of populations decreased with greater compaction. However, in this study, the community of fungi benefited from increased density, probably due to adaptation to the new soil conditions (Shestak \& Busse, 2005).

The results obtained in this study showed a tendency towards a reduction of the studied enzyme activity, however, a significant decrease $(p<0.05)$ was observed in $\mathrm{D}_{1.74}$ soil compared to the control. Dehydrogenase correlated with aeration conditions of the soil, which suggests that the soil compaction or saturation degree influence the activity of this enzyme (Brezezínska et al., 2001). Dick et al. (1988) also detected reduction in the dehydrogenase, phosphatase, arylsulphatase, and amylase activities from 41 to $75 \%$ in compacted soil. Enzyme activities are related to microbial growth (Taylor et al., 2002; Kremer \& Li, 2003), therefore, the reduction in the enzyme activity may be a consequence of the decrease in total bacteria counts with increased compaction. The fungi and the denitrifying bacteria, which had increased with increasing soil density, influenced the enzyme activity less because they represent only a small fraction of the total bacterial community. Dehydrogenase catalyzed the electron transfer, and was influenced by the microbial community and indirectly by soil management (Brezezínska et al., 2001). Phosphatase and urease are important enzymes produced by the microorganisms that promote the transformation of organic compounds, which are unavailable to plants in mineral form (Sylvia et al., 2005). Since soil compaction decreases the activity of these enzymes, nutrient availability and plant growth are consequently affected.

The microorganism counts, aside from denitrifying bacteria, as well as the enzyme activity, aside from urease, decreased significantly in the $0-10 \mathrm{~cm}$ compared to the 10-20 cm soil layer. This decrease can be attributed to the significant decrease of organic matter content and soil $\mathrm{pH}$ between these soil layers. Possibly, the highest content of organic matter in the surface soil layer might be due to the accumulation of corn residues. Organic matter can act as $\mathrm{C}$ and energy 
source which stimulates heterotrophic microorganisms (Vaidya et al., 2008) and influences enzyme activity. The addition of organic matter increased dehydrogenase activity in corn (Masciandaro et al., 2000). It was also observed that phosphatase activity correlated with organic matter and soil moisture (Amador et al., 1997).

\section{CONCLUSIONS}

1. Soil compaction in corn inhibited growth of the total and nitrifying bacteria populations; on the other hand, total fungi and denitrifying bacteria were stimulated.

2. Increased soil density stimulated dehydrogenase and phosphatase activities, but not urease activity.

3. The total bacteria and fungi counts, dehydrogenase and phosphatase enzyme activity, as well as organic matter content and soil $\mathrm{pH}$ increased more in the $0-10 \mathrm{~cm}$ than in the $10-20 \mathrm{~cm}$ soil layer. The inverse was observed for the bacteria counts and soil moisture.

\section{LITERATURE CITED}

ALEXANDER, M. Most probable number method for microbial populations. In: PAGE, A.L.; MILLER, R.H. \& KEENEY, D.R., eds. Methods of soil analysis. Chemical and microbiological properties. 2.ed. Madison, American. Society Agronomy, 1982. Part 2. p.815-820.

ALEXANDER, M. Denitrifying bacteria. In: BLACK, C.A., ed. Methods of soil analysis. Chemical and microbiological properties. Madison, American Society of Agronomy, 1965. Part 2. p.1484-1486. (Agronomy, 9)

AMADOR, J.A.; GLUCKSMAN, A.M.; LYONS, J.B. \& GÖRRES, J.H. Spatial distribution of soil phosphatase activity within a riparian forest. Soil Sci., 11:808-825, 1997.

ARAÚJO, A.S.F. \& MONTEIRO, R.T.R. Indicadores biológicos de qualidade do solo. Biosci. J., 23:66-75, 2007.

BERGSTROM, D.W.; MONREAL, C.M.; MILLETTE, J.A. \& KING, D.J. Spatial dependence of soil enzyme activities along a slope. Soil Sci. Soc. Am. J., 62:1302-1308, 1998.

BRELAND, T.A. \& HANSEN, S. Nitrogen mineralization and microbial biomass as affected by soil compaction. Soil Biol. Biochem., 28:655-663, 1995.

BREZEZÍNSKA, M.; STEPNIEWSKI, W.; STEPNIEWSKA, Z.; PRZYWARA, G. \& WLODARCZYK, T. Effect of oxygen deficiency on soil dehydrogenase activity in a pot experiment with triticale cv. Jago vegetation. Int. Agrophys., 15:145-149, 2001.

BUNT, J.S. \& ROVIRA, A.D. Microbiological studies of some subantartic soils. J. Soil Sci., 6:119-128, 1955.
CASIDA Jr., L.E.; KLEIN, D.A. \& SANTORO, T. Soil dehydrogenase activity. Soil Sci., 98:371-376, 1964.

CLAYTON, H.; Mc TAGGARTT, I.P.; PARKER, J.; SWAN, L. \& SMITH, A. Nitrous oxide emissions from fertilized grassland: A 2-year study of the effects of $\mathrm{N}$ fertilizer form and environmental conditions. Biol. Fert. Soils, 25:252-260, 1997.

DICK, R.P.; MYROLD, D.D. \& KERLE, E.A. Microbial biomass and soil enzyme activities in compacted and rehabilitated skid trail soils. Soil Sci. Soc. Am. J., 52:512-516, 1988.

DICK, R.P. Soil enzyme activities as integrative indicators of soil health. In: PANJHURST, C.E.; DOUBE, B.M. \& GUPTA, V.V.S.R., eds. Biological indicators of soil health. Oxford, CAB International, 1997. p.121-156.

FREDDI, O.S.; CENTURION, J.F.; BEUTLER, A.N.; ARATANI, R.G. \& LEONEL, C.L. Compactação do solo no crescimento radicular e produtividade da cultura do milho. R. Bras. Ci. Solo, 31:627-636, 2007.

GARCIA, M.R.L. \& NAHAS, E. Biomassa e atividade microbiana de solo pastejado por diferentes lotações de ovinos. R. Bras. Ci. Solo, 31:269-276, 2007.

GIAROLA, N.F.B.; TORMENA, C.A. \& DUTRA, A.C. Degradação física de um Latossolo Vermelho utilizado para produção intensiva de forragem. R. Bras. Ci. Solo, 31:863-873, 2007.

JORDAN, D.; PONDER Jr., F. \& HUBBARD, V.C. Effects of soil compaction, forest leaf litter and nitrogen fertilizer on two oak species and microbial activity. Appl. Soil Ecol., 23:33-41, 2003

KREMER, R.J. \& LI, J. Developing weed-suppressive soils through improved soil quality management. Soil Till. Res., 72:193-202, 2003

LANZANOVA, M.E. Atributos físicos do solo em sistema de integração lavoura-pecuária sob plantio direto. R. Bras. Ci. Solo, 31:1131-1140, 2007.

LEE, W.J.; WOOD, C.W.; REEVES, D.W.; ENTRY, J.A. \& RAPER, R.L. Interactive effects of wheel-traffic and tillage system on soil carbon and nitrogen. Soil Sci. Plant Anal., 27:3027-3043, 1996.

LI, Q.; ALLEN, H.L. \& WILSON, C.A. Nitrogen mineralization dynamics following the establishment of a loblolly pine plantation. Can. J. For. Res., 33:364-374, 2003.

LIMA, H.V.; LIMA, C.L.R.; LEÃO, T.P.; COOPER, M.; SILVA, A.P. \& ROMERO, R.E. Tráfego de máquinas agrícolas e alterações de bioporos em área sob pomar de laranja. R. Bras. Ci. Solo, 29:677-684, 2005.

MARTIN, J.P. Use of acid, rose bengal, and streptomycin in the plate method for estimating soil fungi. Soil Sci., 69:215-232, 1950.

MASCIANDARO, G.; CECCANTI, B.; RONCHI, V. \& BAUER, C. Kinetic parameters of dehydrogenase in the assessment of the response of soil to vermicompost and inorganic fertilisers. Biol. Fert. Soils, 32:479-483, 2000. 
Mc GARITY, J.W. \& MYERS, M.G. A survey of urease activity in soils of Northern South Wales. Plant Soil, 27:217-238, 1967.

MARTENS, D.A.; JOHANSON, J.B. \& FRANKENBURGER Jr., W.T. Production and persistence of soil enzymes with repeated additions of organic residues. Soil Sci., 153:53-61, 1992.

MIRANSARI, M.; BAHRAMI, H.A.; REJALI, F.; MALAKOUTI, M.J. \& TORABI, H. Using arbuscular mycorrhiza to reduce the stressful effects of soil compaction on corn (Zea mays L.) growth. Soil Biol. Biochem., 39:2014-2026, 2007.

PENGTHAMKEERATI, P.; MOTAVALLI, P.P.; KREMER, R.J. \& ANDERSON, S.H. Soil compaction and poultry litter effects on factors affecting nitrogen availability in a clay pan soil. Soil Till. Res., 91:109-119, 2006.

RIFFALDI, R.; SAVIOZZI, A.; LEVI-MINZI, R. \& CARDELLI, R. Conventional crop management effects on soil organic matter characteristics. Agronomie, 23:45-50, 2003.

ROSOLEM, C.A.; FERNANDEZ, E.M.; ANDREOTTI, M. \& CRUSCIOL, C.A.C. Crescimento radicular de plântulas de milho afetado pela resistência do solo à penetração. Pesq. Agropec. Bras, 34:821-828, 1999.

RUSER, R.; FLESSA, H.; RUSSOW, R.; SCHMIDT, G.; BUEGGER, F. \& MUNCH, J.C. Emission of $\mathrm{N}_{2} \mathrm{O}, \mathrm{N}_{2}$ and $\mathrm{CO}_{2}$ from soil fertilized with nitrate: Effect of compaction, soil moisture and rewetting, Soil Biol. Biochem., 38:263$274,2006$.

SAS Institute. Statistical Analysis System. SAS/STAT use's guide (Version 6). 3.ed. Cary, 1990. 705p.

SCHMIDT, E.L. \& BELSER, L.W. Nitrifying bacteria. In: PAGE, A.L.; MILLER, R.H. \& BKEENEY, D.R., eds. Methods of soil analysis: Chemical and microbiological properties. Madison, American Society of Agronomy, 1982. Part 2. p.1027-1042.
SHESTAK, C.J. \& BUSSE, M.D. Compaction alters physical but not biological indices of soil health. Soil Sci. Soc. Am. J., 69:236-246, 2005.

SMELTZER, D.L.K.; BERGDHAL, D.R. \& DONNELLY, J.R. Forest ecosystem responses to artificially induced soil compaction. II. Selected soil microorganism populations . Can. J. For. Res., 16:870-872, 1986.

SYLVIA, D.M.; HARTEL, P.G.; FUHRMANN, J.J. \& ZUBERER, D.A. Principles and applications of soil microbiology. New Jersey, Pearson Prentice Hall, 2005. 640p.

TABATABAI, M.A. \& BREMNER, J.M. Use of p-nitrophenyl phosphate for assay of soil phosphatase activity. Soil Biol. Biochem., 1:301-307, 1969.

TABOADA, M.A. \& ALVAREZ, C.R. Root abundance of maize in conventionally-tilled and zero-tilled soils of Argentina. R. Bras. Ci. Solo, 32:769-779, 2008.

TAYLOR, J.P.; WILSON, B.; MILLS, M.S. \& BURNS, R.G. Comparison of microbial numbers and enzymatic activities in surface soils and subsoils various techniques. Soil Biol. Biochem., 34:387-401, 2002.

TEEP, R.; BRUMME R.; BEESE, F. \& LUDWING, B. Nitrous oxide emission and methane consumption following compaction of forest soils. Soil Sci. Soc. Am. J., 68:605611,2004

TORBERT, H.A. \& WOOD, C.W. Effects of soil compaction and water-filled pore-space on soil microbial activity and N losses. Comm. Soil Sci. Plant Anal., 23:1321-1331, 1992.

VAIDYA, G.S.; KESHAB, S.; KHADGE, B.R.; JOHNSON, N.C. \& WALLANDER, H. Organic matter stimulates bacteria and arbuscular mycorrhizal fungi in Bauhinia purpurea and Leucaena diversifolia plantations on eroded slopes in Nepal. Restor. Ecol., 16:79-87, 2008.

WHALLEY, W.R.; DUMITRU, E. \& DEXTER, A.R. Biological effects of soil compaction. Soil Till. Res., 35:53-68, 1995. 